\title{
DE SURINAAMSCHE TAALTUIN
}

DOOR

W. R. MENKMAN

II

Bestaat er iets, dat men Surinaamsch Nederlandsch zou kunnen noemen?

Prof. Van Ginneken heeft gemeend van wel, want hij behandelde het als een onderdeel van het West-Indisch, op bladz. 275 van zijn Handboek der Nederlandsche Taal I. Veel zegt hij er niet over; een staaltje der ,ietwat poovere Surinaamsch-Nederland„sche poëzie" van A. W. Marcus (waarin Creoolsche taalfouten worden gesignaleerd) en een (weinig gecommentarieerd) briefje van een bij de Herrnhutters opgevoed Caraibenmeisje aan haar leriman, zie daar alles wat wij aangaande het Hollandsch der Surinamers in dit handboek aantreffen.

Veel is het niet en toch, toen Van Ginneken's werk verscheen, in 1913, het laatste jaar van mijn verblijf in Suriname, vielen er in de taal der inheemschen aldaar nog al wat afwijkingen van het gebruikelijke moderne Nederlandsch te constateeren, welke verdiend hadden in een werk als het genoemde vermeld te worden.

De Encyclopaedie van Nederlandsch West-Indië (bladz. 503: Nederlandsch) zegt alleen iets over de zuiverheid van het in Suriname gesproken Hollandsch, over de moederlandsche gewestelijke uitdrukkingen, welke er in voorkomen en over de insluipsels uit het Fransch, het Portugeesch en het Engelsch, alles heel in het algemeen.

Heeft er dus in het moederdand blijkbaar voor de materie in kwestie nooit veel belangstelling bestaan, in Suriname zelf was indertijd de taal een onderwerp, waarover Hollanders en inheemschen het wel eens met elkander aan den stok konden krijgen.

Ik herinner mij dat een Hollandsch onderwijsman zich eens verstout had een lijstje te publiceeren van wat hij meende als Surinamismen te moeten brandmerken. Door een Surinaamsch auto- 
didact werd deze paedagoog toen in de plaatselijke pers op ongezouten wijze terecht gewezen; de Hollander wist niet wat onder Surinamismen verstaan moet worden en had blijk gegeven van totaal gemis van taaleruditie.

Aangezien ik op mijn beurt er beter afgekomen ben, toen ik mij, eenige jaren geleden, in de West-Indische Gids ${ }^{1}$ ) een leekenpraatje over het Nederlandsch in Suriname veroorloofd had, kan ik den moed vinden aan het toen ten beste gegevene nog iets toe te voegen.

Destijds heb ik wel melding gemaakt van de Surinaamsche eigenaardigheid om het werkwoord beletten te gebruiken met een persoon als voorwerp („de politie heeft hem belet”), maar ik heb daar toen niet bij gezegd, dat wij ook in dit geval met een archaïsme te doen hebben. Het Woordenboek der Nederl. Taal verwijst naar den Bijbel (I Thessalonicenzen, 2. 18): „maer de Satan „heeft ons belet"; in mijn exemplaar (Statenvert. uitg. 1906) staat maar met twee a's en is h e t cursief tusschengevoegd. Ook bij Vondel - en bij andere, minder beroemde 17e eeuwsche schrijvers - treft men den vorm zonder het aan.

Een Surinaamsche uitdrukking, waarmede ik vroeger geen raad wist, is : „hij is ziek, hij ligt met de dokter”. Totdat ik haar aantrof bij den $18 \mathrm{e}$ eeuwschen Nederlandschen zee-officier Cornelius de Jong, in diens Reize naar de Car. Eilanden in de jaren 1780 en 1781 (Haarlem 1807). Deze auteur geloofde blijkbaar in de legende van de onderzeesche koperbank, niet ver van Sint Eustatius, door de aanwezigheid van welke bank de in de nabijheid gevangen visch soms vergiftig zijn zou. Op een dag werd men aan boord van de Mars ziek, na het nuttigen van versche visch; „wij” - de officieren -, zegt De J., „lagen allen met den dokter". Of deze zegsman ooit in Suriname geweest is, weet ik niet, maar het lijkt veel waarschijnlijker, dat dergelijke uitdrukkingen uit Nederland overgebracht, dan dat zij in de West ontstaan zouden zijn.

In de West, niet speciaal in Suriname, want op de eilanden hebben wij natuurlijk hetzelfde Nederlandsch gebracht als in de vastelandskoloniën. Het Surinaamsche (lees oud-Hollandsche) voeteeren komt ook voor in het door Mr. De Gaay Fortman gepubliceerde, vroeg 18 e eeuwsche Curaçaosche dagboek ${ }^{2}$ ); 3 Febr. 1713: „... die alle naar Piscaderisbaay voeteerden."

De eigenaardigheid van Surinamers om het bijv. nw. onnoodig te gebruiken in de beteekenis van onnoozel (onbelangrijk, onbe-

1) De Surinaamsche Taaltuin, W.-I. G. XIV, p. 244 e.v.

2) W.-I. Gids, VI, p. 241 e.v. 
teekenend, minderwaardig) heb ook ik lang voor krompraterij gehouden, maar ik ben daarvan teruggebracht door een zekere passage in het Korte Historiael van David Pietersz. de Vries, den Hoornschen zeeman uit den aanvang der 17e eeuw, die geen litteraire pretenties had, maar wel een bijzonder pittig en kleurig Hollandsch schreef.

Als scheepsbevelhebber was De Vries niet altijd goed te spreken over de vakbekwaamheid, noch over den moed zijner onderhoorigen; de grootste praatjesmakers waren niet altijd haantje de voorste's wanneer er gevochten worden moest tegen Turk of Spanjool.

Een maalmoest men zich in de Middenlandsche Zee (bij Cartagena in de buurt) verdedigen tegen twee roofschepen en het volk werd dus aan dek geroepen, maar verscheen niet al te vlug. „Eyn"delijck”, zegt De Vries, „quam de onnodighste eerst boven, „waerop de anderen volghden.” Blijkbaar was de man, die het goede voorbeeld gaf, niet degeen wiens aanwezigheid het minst noodig was, maar degeen van wien De Vries het minst verwacht had.

Of van hetgeen vroeger het Surinaamsche Hollandsch onderscheidde van het in het moederland gebruikelijke (archaïsmen, maar ook wel bepaalde onzuiverheden) nog veel is blijven leven, weet ik niet; in een kwart eeuw kan er veel veranderd zijn. Bepaalde redenen echter om veel uitslijting of snelle evolutie op taalgebied te verwachten, zie ik niet.

Evenals vroeger op zee (zie capt. Marryat's verhalen), gold het ook in Suriname wel als een aardigheid, iemand die in een hangmat lag te slapen, er uit te laten vallen, door het touw door te snijden; men zei dan: „ze hebben zijn hangmat gesneden” en vond dat een heel gewone uitdrukking. Welnu, onlangs kwam in een Surinaamsch blad (redacteur een volbloed Hollander, maar lang in Suriname) een berichtje voor, waaruit bleek dat iemand zich beklaagd had over „het kappen” van zijn boot. Bij analogie redeneerend, zou men tot de conclusie kunnen komen, dat in dit geval het touw doorgekapt was, waar de boot aan vastlag, maar uit latere berichten bleek, dat de boot aan stukken gehakt was.

Wie meenen mocht, dat de Duitsche Herrnhutters, die als zendelingen, onderwijzers en kooplieden al zoo lang in het Surinaamsche volksleven een rol gespeeld hebben, het Nederlandsch in Suriname met een groot aantal germanismen verrijkt moeten hebben,maakt zich noodeloos ongerust. Het is overigens wel eigenaardig, dat onze taal in een Nederlandsch gewest haar plaats 
heeft kunnen veroveren, óók door de (zeer verdienstelijke) werkzaamheid van vreemdelingen, die maar zelden hun typische accent konden afleggen - en zelf het Nederlandsch, althans voor een deel, ter plaatse hadden moeten leeren.

Een der Surinaamsche bladen nam onlangs in haar rubriek Taal en Letteren een protest over tegen germanismen als vroegstens, voor op zijn vroegst. In hetzelfde blad echter verscheen kort daarop, zonder commentaar of correctie, een correspondentie uit Nickerie, waarin over een vereeniging gesproken werd, welke de schrijver "op zich" een goede instelling achtte; en over menschen wier ,eenvoud" kort geleden nog ,beklemtoond" was.

Maar deze soort taalmishandeling is niet meer specifiek Surinaamsch; de groote pers h.t.l. geeft er schier dagelijks staaltjes van te zien.

Amsterdam, 1 Mei 1937. 